\title{
Challenges of Accounting Practices and Its Prospects: Evidence from Small and Medium Enterprises of Selected Districts, South West Shoa Zone, Ethiopia
}

\author{
Solomon Terfasa Dinka \\ Lecturer, Department of Accounting and Finance, Ambo University, Ethiopia
}

\begin{abstract}
Small and Medium Enterprise are neglected area in the accounting and finance function which require support in the functional areas of their businesses. The study aimed to assess the accounting practices and its prospects in small and medium enterprise of south west Shoa zone, Ethiopia with special references to recordkeeping, financial reporting, financial planning, analysis, and the use of accounting information system. The study employed primary data which obtained from small and medium enterprises through questionnaires. The total population of the study was 1,005 , out of which 287 were taken as a sample by using probability sampling technique. Data obtained from primary sources were processed through SPSS version-22. The study concluded that, most of small and medium enterprises of the study areas sometimes involved in preparation of profit and loss accounts. Again, the study found that, nearly all of the small and medium enterprises of the study areas who tried to maintain records were followed GAAP. Hence, the newly adopted accounting standard i.e., IFRS was generally not in use in the study areas. Moreover, the study concluded that, most small and medium enterprises in the study areas did not engaged in the preparation of cash flow budget and analyzing trends in sales. Finally, the study suggested that, small and medium enterprises better to improve the quality of their reports by adopting internationally accepted accounting standards such as IFRS. In addition, accounting training programs for small and medium enterprises should be initiated by concerned bodies -especially, the trade and industry bureaus, academic staffs, and the technical and vocational schools. Most importantly, the government should put in place a regulatory body to ensure that small and medium enterprises keep proper books and prepare final accounts.
\end{abstract}

Keywords: Challenges, Accounting Practices, Prospects, Small and Medium Enterprises

DOI: $10.7176 /$ RJFA/10-11-07

Publication date:June $30^{\text {th }} 2019$

\section{Introduction}

Over the years, there is a growing recognition of the important roles of Small and Medium Enterprises play in the economic transformation of every developing economy (Palich \& Longernecker, 2008). Development strategists have postulated the progressive contributions of small and medium enterprises to speed up the rate of economic growth particularly in the developing countries of the world. Globally, Small and Medium Enterprises contribute a significant role in addressing job creation, poverty reduction, and economic transformation. However, most of these enterprises fall without achieving their expectation due to weak accounting practices (Olatunji, 2013).

Decision usefulness theory postulates that, accounting provides different information to meet the needs of the different decision makers. However, lack of such accounting practices as sufficient record keeping, material control and effective budgeting are likely to aggravate the problems faced by small and medium enterprises (Ohachosim, 2014). For instance, Davies and Pickernell, (2012) suggested that, accounting practice is important because it allows business enterprises to understand their financial position and condition at any particular period of time which helps the development of strategies and to make businesses appropriate decision makings. A business's accounting practice refers to the method by which its accounting policies are implemented and adhered to on a routine basis, typically by an accountant, and accounting professionals. An accounting practice is intended to enforce a firm's accounting guidelines and policies. It exists as the daily recording of financial data that is important to the evaluation and monitoring of the firm's economic activities. Now days, as physical and digital worlds have grown and integrated, accounting information systems are now generally computer-based methods for tracking accounting activities which compliment other enterprise-wide technologies and information management resources (Bohman \& Boter, 1984; Keasy \& Short, 1990; King, 2007; Lalin \& Sabir, 2010; Zoubi \& Al-Khazali 2011).

\subsection{Research Problem and Objectives}

Despite the importance of proper accounting practices such as financial reporting, management accounting, and control practices, it is unfortunate to find that these practices are often inadequate in small and medium enterprises. Moreover, except for tax issues some form of profit and loss account, balance sheet, cash flow statement, and production report, are infrequently maintained in small and medium enterprises (Yousef, 2013). The fact that, financial statements of business enterprises are used by a diverse group of users for making sound economic 
decision they required set of accounting standard to improve the credibility and reliability of financial statements. Accounting standards are required to meet a basic need of managers, investors, and creditors to compare results and financial conditions of different segments of firms, different periods of firms, and different firms $\&$ different industries (Walton, 2000).

Basically, the most important factors that contribute to success or failure of business enterprises are identified as internal and external factors. For instance, the external factors consist of technological advancement, financing, social, economic and political conditions, competition, government regulation, and environmental factors. On the other hand internal factors comprise, accounting system and financial management and managerial accounting practices (Okoli, 2011). Most importantly, the inability to use an appropriate financial reporting and management accounting practices is one of the obstacles for the survival and growth of small and medium enterprises (Jones et al, 2012). In the same way, according to (Walton, 2000; Dawuda \& Azeko, 2015) poor record keeping and inefficient use of accounting information are another major cause for the failure of enterprises. Hence, as it tried to described in the above sections; the problems in the accounting practices along with the gap between the theories and the practices with special references to recordkeeping, financial reporting, financial planning and analysis, and the use of accounting information system in small and medium enterprises of South west Shoa zone call for extensive research.

\section{Reviews of Related Literatures}

\subsection{Theories Related to Small and Medium Enterprises}

\subsubsection{Output-Demand Theory}

Output-Demand theory assumes a necessity for the growth of small and medium enterprises is that there is a market for their products and services. Hence, the small and medium enterprises will have a tendency to develop a cyclical link among the economy as a whole. However, small and medium enterprises will also develop in competition with large enterprises in the formal sector and their progress will be guarded by formal sector monopolies. Structural adjustment and other policies that hurdle such monopolies, and attempt to create more competition will consequently be useful to the small and medium enterprises. Furthermore, a customized sequence of the outputdemand theory tied small and medium enterprises and sustainable development and transformation of the rural agrarian economy (Christopher et al, 2006).

\subsubsection{Labor Surplus Theory}

Labor supply theory postulated that, the driving force for the encouraging small and medium enterprises growth is the surplus of labor supply that is not easily engaged in the public sectors or large private business enterprises. Moreover, the small and medium enterprises sector develops in reaction to an increase in joblessness, and people who are unable to find employment in the formal sector have a preference to take part in these sectors. Another argument under labor supply theory is that, it links rural non-agricultural activities to the rural surplus labor (Bryceson \& Jamal, 1997).

\subsubsection{Firm's Growth Theory}

This theory suggests, economic growth and industrialization is instrument which accelerate the transformation of small and medium enterprises towards large-scale enterprises. Nevertheless, the fact that small and medium enterprises did not usually compete directly with large business enterprises can be considered as the critics of firm's growth theory (Ryan, 2005).

\subsection{Accounting Practices}

Accounting practices refers the routine approach in that the daily activities of a business firms are accumulated and recorded. Accounting practices are related to the technique by which its accounting policies are implemented and adhered to on everyday basis, usually by accounting professionals (Gupta, 2012). Accounting practices also refers to the normal, practical function of accounting policies that occurs in a business entity (Stefanou, 2006; Padachi, 2012).

\subsubsection{Record Keeping}

Small and medium enterprises are required to keep proper accounting records in the day to day activities of the business. For instance, According to Reed, (2010), proper record keeping provides evidence of how the transactions were handled and prove the steps that were taken in order to match with business standards. A good accounting record keeping makes small and medium enterprises to place properly and moreover check for misuse of asset of their business. Likewise, keeping proper books of records is a crucial to the progress and continued existence of business enterprises (Ademola, 2012). The small and medium enterprises believe that, spending much time and expenses in keeping the records are not that useful for them. In addition, one more reason for not keeping records is that, it requires technical skills and knowledge which is not acquired by small and medium enterprises (Amaoke, 2013).

\subsubsection{Financial Reporting}

Financial reporting deals with the nature, frequency and purpose of financial reporting. According to McMahon, 
(1998) the financial reports for small and medium enterprises are prepared mainly by external accountants at yearly intervals, and they usually include only the profit and loss statement and the balance sheet. Similarly, the presentation of financial reports appears to be very much influenced by tax authority and legal reporting requirements. In addition, a study by Hopper et al, (1999) on small and medium enterprise found that, financial reports which are un attempted are particularly useful for decision makings for small and medium enterprises.

\subsubsection{Financial Planning, Analysis, and Control}

Financial planning, analysis, and control deal with financial objectives and targets, financial budgeting and control, and analysis and interpretation of financial performances. Financial planning is very essential for all business. Although, planning can be undertaken differently by small and medium enterprises as compared to large ones the reality is that, planning must be practiced. For instance in a vibrant small and medium enterprises the planning function is given very little consideration while it may be the most significant function that the managers required to undertake (Walker \& Petty, 2001). The main aspects of short-term financial planning are profit planning and cash planning. Profit planning is made by compiling pro forma financial statements such as income statements and balance sheets. Cash planning is also done by generating a cash budget. The financial planning process can be approached in different ways; but, the basic components include forecasting, developing a course of action, and generating projected financial statements associated with a given set of forecast and actions (Gitman, 2010).

\subsubsection{Accounting Information System}

Accounting information is an information system designed to make the accomplishment of accounting function possible. It process data and transactions to provide users with the information they need to plan control, and operate their business. It can be a manual system, or a computerized system using computers. Apart from its type, accounting information system designed to collect, enter, process, store and report data and information (Evaraert et al, 2006; Jayabalan \& Dorasamy, 2009; Zhou, 2010). In fact, in the recent years, our world becoming a digital world as a result, business activities and exchanged are becoming more complex and integrated. However, various evidences shows that, in small and medium enterprises the use of accounting information still inadequate.

\section{Empirical Evidences}

Azhar et al, (2010) assessed the components of financial management \& techniques practiced by the small and medium enterprises in Malaysia. The results of the study found that, three components of financial management to be categorized as core components practiced by the small and medium enterprises namely; financial planning $\&$ control, financial accounting, \& working capital management. The study identified the other three components which are financial analysis, management accounting, \& capital budgeting classified as complementary components which are practiced by the small and medium enterprises because of the fact that, the small share of the small and medium enterprises using these components in the management of their business.

Okoli, (2011) on his part examined the accounting system of small and medium enterprises. The study indicated that, small and medium enterprises did not evaluate their performances due to inadequate record keeping practices. Likewise, the study found that, there is a need for sufficient record keeping that will helps the owners' to measure their business performances. Maseko \& Manyani, (2011) evaluated accounting record keeping practices of small and medium enterprises of Zibababwe for performance measurement. The study identified that, -especially, because of accounting knowledge \& the raise in the cost of hiring professional accountants, small and medium enterprises did not keep complete accounting records.

Tafa, (2011) examined the Accounting Practices of Small and Medium Sized Enterprises and its Effect on Access to Finance in Addis Ababa. The study pointed out that, the majority of the studied Enterprises have no formal accounting practices. Moreover, the study investigated, variables like capital, management level of education, \& ages of the firms' were the major challenges of firms' accounting practices. In addition, study conducted by Kofi et al, (2014), in Ghana found, most small and medium enterprises of the study areas did not prepare financial statement for tax assessment because of poor financial record keeping, lack of knowledge about financial report, \& lack of computerized accounting systems. Kalainathan \& Vijayarani, (2013) have done a study on accounting system in Small Scale Enterprises \& their study pointed out, accounting system in the Small Scale Enterprises was not good, but they have primary books to enter the transactions \& also there is no legal requirement to prepare the accounting records.

A study by Olatunji, (2013) also showed that, an effective accounting system in small and medium enterprises has a great effect on their business performances. The study suggested that, higher education institutions need support for small and medium enterprise. Amoako, (2013) explored the accounting practices of SMEs in Ghana. The results revealed that SMEs did not keep proper books of accounts due to the fact that inability of owners' to realize the importance of accounting records \& lack of basic accounting knowledge. Isaac et al, (2014) conducted a study on an Adoption of Accounting Practices and its Effects on small and medium enterprises of Sachet Water Producers in Northern Region of Ghana. The study found that, there were numerous perceived factors which influence the adoption of accounting practices in the study area. For instance, lack of adequate training, and lack of accounting knowledge and skills few among others. Most importantly, as per the findings, illiteracy was the 
major reason for not to maintain separate records for personal and business expenditures.

Amoako et al, (2014) in their parts investigated that, most of the small and medium enterprises did not keep complete accounting records as a result of numerous factors namely: lack of book keeping skills on the part of owners or managers and the high cost involved in adopting a good accounting system. Similarly, Md. Asaduzzaman, (2016) undertake a survey on Accounting and Financial Reporting Practices of small and medium enterprises in Bangladesh. The result indicated that, most small and medium enterprises did not keep accounting records because they recognize that it is difficult to keep the system as well as unnecessary even it makes the enterprise in order to pay more tax.

Marahi D. \& Pasha D., (2017) also conducted a study on Accounting Practices and Financial Reporting in Case of Arba Minch Town, Ethiopia. Their study found that, the bookkeeping practices in small and medium enterprises were not organized to produce the required information for decision makers. In addition the result of the study revealed that, small and medium enterprises operating in construction sector maintained all receipts\& invoices of their transaction in a systematic manner than the other sectors, whereas none of urban agricultural small and medium enterprises kept these activities well. The study further pointed out that, the majority of small and medium enterprises encounter challenges in complying with accounting requirements \& that most them outsource the preparation of financial statements to specialist services.

Finally, Justice, (2017) undertakes a study on Financial Accounting Practices of Small and Medium Scale Enterprises in Municipality of Ghana'. The results revealed that majority of small and medium enterprises failed to keep proper accounting records pertaining to their businesses. As a result, it was not easy for the ownermanagers to decide the profit earned or loss incurred in the business for a given period of time. The researcher in his study further explained the main reasons for the business failure to keep proper accounting records \& prepare a complete set of financial statements involved, high cost of hiring qualified accountants \& lack of accounting knowledge.

\subsection{Gap Identified}

Although, many studies have been done on the general aspects of accounting practices in small and medium enterprises, few have been done specifically on financial, reporting, financial planning, analysis, and control in small and medium enterprises in Ethiopia. As a result, little is known about the gap between the theory \& the real practices of accounting in small and medium enterprises along with its prospects. With this in mind, it is difficult to persuade business owners, business practitioners, government bodies, and other stakeholders of the need until additional evidences will provide on challenges of accounting practices and it future. Thus, this study aimed to assess the challenges of accounting practices and its prospects in small and medium enterprises in selected districts of south west Shoa zone, Ethiopia.

\section{Research Design and Methodology}

The research approach adopted in the study was a quantitative approach. The total population of the study was 1,005 Small and Medium Enterprises, out of which 287 was taken as a sample using probability sampling technique. The study used the primary data which were gathered from small and medium enterprises of the study areas. Multiple choices item, a combination of dichotomous, and Likert scale questions were used for the survey. To process the data, SPSS versio-22 was also used. In addition, to visualize the data tables, bar graphs, and pie charts were used. 


\section{Results and Discussions}

Figure 4.1: Gender compositions of the Respondents

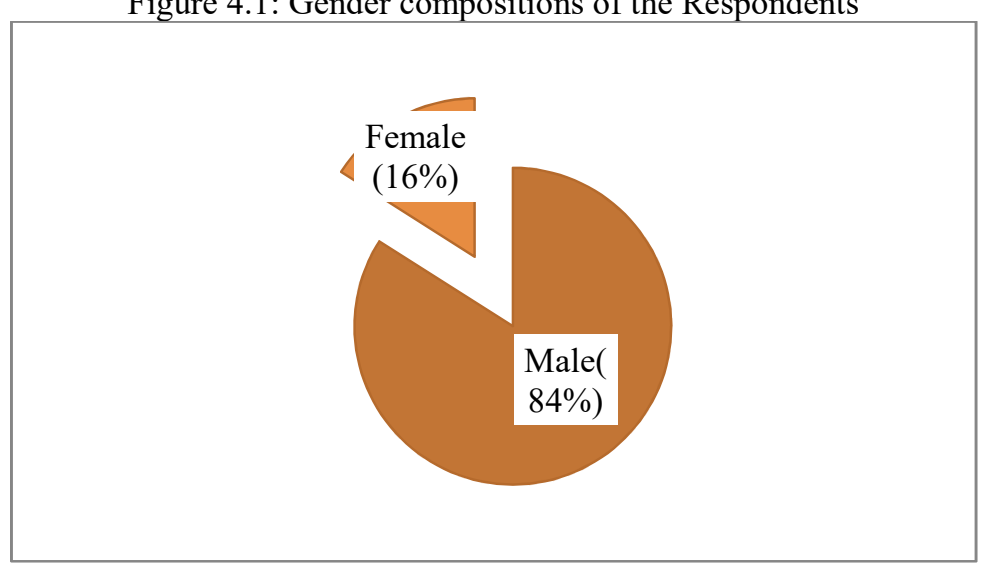

Source: Survey of small and medium enterprises, 2019

Regarding with the sex ratio of the respondents the survey results shows about $84 \%$ of the respondents were male when compared to $16 \%$ of the respondents who were female. This implies that, the women entrepreneurs' engagement in business activities were very low as compared to men. (Figure 4.1 shows details)

Figure 4.2 Distribution of business types

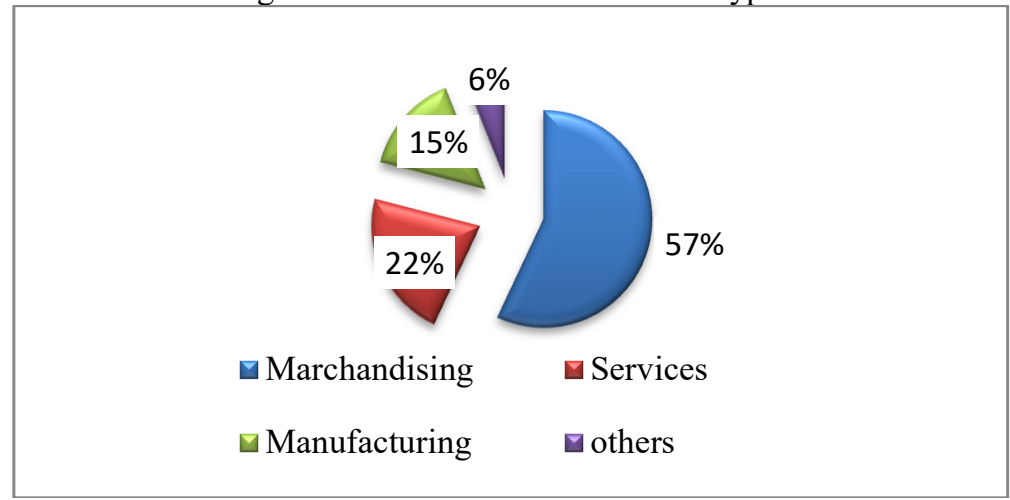

Source: Survey of small and medium enterprises, 2019

The study includes four types of business engaged in merchandizing, manufacturing, services, and others activities. As a result, figure 4.2 above depicts that, $57 \%$ \& $22 \%$ of the small and medium enterprises were engaged in merchandizing \& service business respectively. Similarly, about $15 \%$ and $6 \%$ of the respondents were engaged in manufacturing and other sectors such urban agriculture respectively. This shows that, in the study areas, merchandise business sectors comprise significant number of small and medium enterprises.

Figure 4.3 Distribution of Education Level

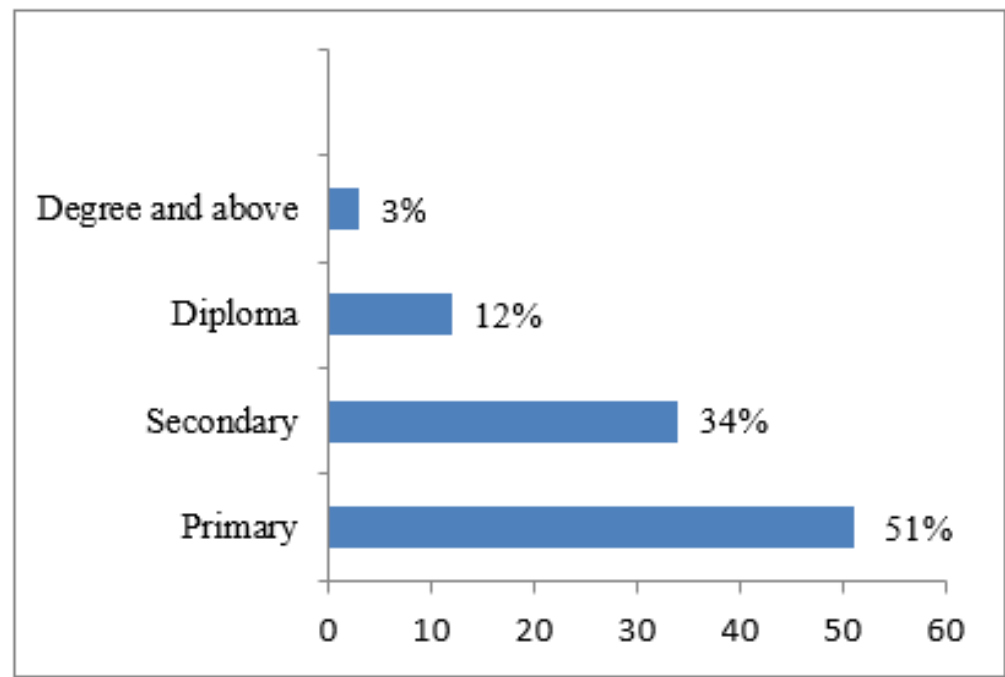

Source: Survey of small and medium enterprises, 2019 
As it can be observed from figure 4.3 above, about $51 \%$ and $34 \%$ of small and medium enterprises owners' have primary and secondary school education respectively; while, about $12 \%$ were diploma holders and very few, that is 3\% hold degree and above. As a result, this finding implies that, most owners' of small and medium enterprises of the study areas did not have sufficient education to better manage their business operations.

Table 4.1: Do you maintain profit and loss account for your business?

\begin{tabular}{|c|c|c|c|}
\hline \multicolumn{2}{|l|}{ Response } & Frequency & Percentage \\
\hline Never & & 41 & $14 \%$ \\
\hline Sometimes & & 220 & $77 \%$ \\
\hline Always & & 26 & $9 \%$ \\
\hline & Total & 287 & $100 \%$ \\
\hline
\end{tabular}

Source: Survey of small and medium enterprises, 2019

Table 4.1 above depicts whether small and medium enterprises maintained profit and loss account or not. As a result, about $77 \%$ of the respondents sometimes maintained profit and loss account; whereas about $14 \%$ of the respondents never keep profit and loss accounts. Again, only $9 \%$ of the respondents always keep profit and loss account. This shows that, most owners' of small and medium enterprises did not maintain profit and loss account on regular basis. The respondent further explained that, lack of core accounting and businesses knowledge were the potential challenges for the majority of the owners' not to maintain profit and loss account.

Figure 4.4: Accounting system adopted

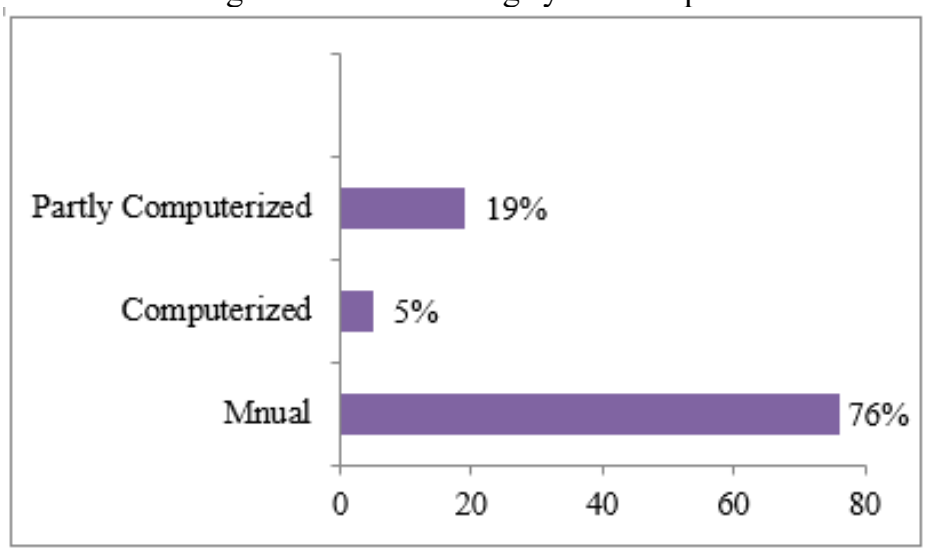

Source: Survey of small and medium enterprises, 2019

As it is presented in the figure 4.4 above, about $76 \%$ of the respondents followed manual accounting system; while, about $19 \%$ of the respondents partly employed computerized accounting system. Likewise, only $5 \%$ of the respondents were adopted computerized accounting in their operations. The respondent further justified that, lack of computer skill is the major challenges of the business owners' not to adopt computerized accounting system. This finding implies that, most of small and medium enterprises in the study areas employed manual accounting system.

Table 4.2: Basis of accounting adopted in small and medium enterprises

\begin{tabular}{lcc}
\hline Response & Frequency & Percentage \\
\hline Cash basis & 132 & $46 \%$ \\
Accrual basis & 155 & $54 \%$ \\
Total & 287 & 100 \\
\hline
\end{tabular}

Source: Survey of small and medium enterprises, 2019

Table 4.2 above depicts basis of account that small and medium enterprises adopted. Accordingly, more half (54\%) of the respondents adopted accrual basis of accounting; whereas, about $46 \%$-especially, those who engaged in services business adopted cash basis of accounting. This implies that, the majorities of small and medium enterprises of the study areas were used accrual basis of accounting. 
Figure 4.5: Accounting standards followed by SMEs' (International standards)

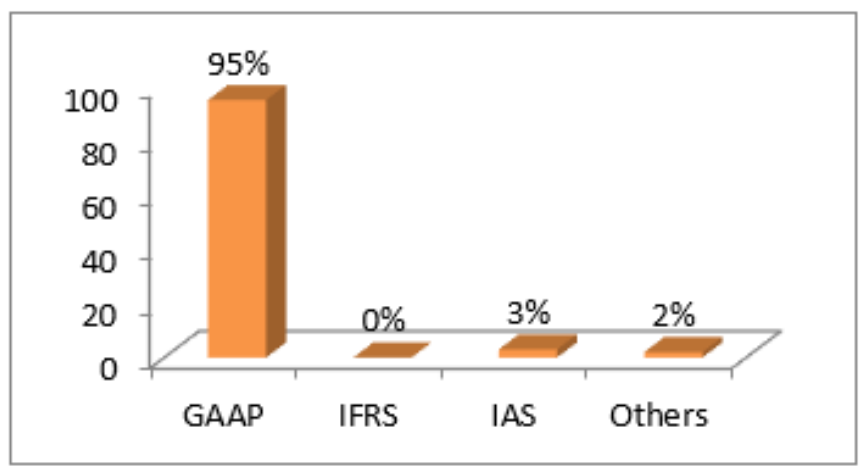

Source: Survey of small and medium enterprises, 2019

Regarding with accounting standards, figure 4.5 depicts the accounting standard followed by small and medium enterprises. Accordingly, about $95 \%$ of the respondent followed GAAP; whereas; $3 \%$ and $2 \%$ of small and medium enterprises' followed IAS and other accounting standards respectively. Similarly, none of the respondents followed IFRS in the study areas. This indicates that, the significant majority of small and medium enterprises' in the study areas still followed GAAP while at present time accounting standards were already shifted to IFRS

Table 4.3: Do you prepare cash flow budget for your business?

\begin{tabular}{|c|c|c|}
\hline Response & Frequency & Percentage \\
\hline Yes & 34 & $12 \%$ \\
\hline No & 253 & $88 \%$ \\
\hline Total & 287 & 100 \\
\hline
\end{tabular}

Source: Survey of small and medium enterprises, 2019

Table 4.3 above asks whether respondents maintain cash flow budget for your business or not. As a result, $88 \%$ of the respondents did not prepare cash flow budget whereas, only $12 \%$ of the respondents did have. These finding shows that, still the majority of small and medium enterprises' did not engaged in preparation of cash flow budget. Hence, this can results in poor financial decision by business operators.

Table 4.4: Do you analyze the trend of your sales?

\begin{tabular}{|c|c|c|}
\hline Response & Frequency & Percentage \\
\hline Yes & 49 & $17 \%$ \\
\hline No & 238 & $83 \%$ \\
\hline Total & 287 & 100 \\
\hline
\end{tabular}

Source: Survey of small and medium enterprises, 2019

As it can be seen from table 4.4 above about analysis of trends in sales, about $83 \%$ of the respondent did not undertake analysis of their sales trends; whereas, $17 \%$ of did it. Most importantly, as per the respondents' justification, most of small and medium enterprises operators did not have sufficient understanding about financial analysis and so that, the accounting experiences and practices are yet very poor which call for further attention. This result shows that, large number of small and medium enterprises of the study areas did not engaged in analyzing trends in their sales as a result; owners' unable to make sound decision regarding sales.

Table 4.5: Do you maintain separate record/s for your business and for your personal asset/s?

\begin{tabular}{|c|c|c|}
\hline Response & Frequency & Percentage \\
\hline Yes & 75 & $28 \%$ \\
\hline No & 212 & $72 \%$ \\
\hline Total & 287 & 100 \\
\hline
\end{tabular}

Source: Survey of small and medium enterprises, 2019

Table 4.5 above presents whether the respondents maintain separate records for their business and for their personal assets or not. As a result, $72 \%$ of the respondents did not have separate records; whereas, about $28 \%$ of the respondents have separate records. Moreover, the respondents replied that, lack of knowledge about business entity concept is the main reason not to maintain separate records. This implies that, the resources supplied by owners' and the resources controlled by entity were mixed in most small and medium enterprises of the study areas.

\section{Findings}

The study found that, merchandise businesses take the largest share of small and medium enterprises in the study areas. Again, most (51\%) of small business enterprises operators have no ample education to better manage their 
businesses. Regarding preparation of profit and loss accounts, the results showed that, most $(77 \%)$ of the small and medium enterprises of the study areas sometimes engaged in maintaining profit \& loss account-especially, due to lack of core accounting \& businesses knowledge. The study investigated that, most (76\%) of small and medium enterprises of the study areas employed manual accounting system. Likewise, the more than half (54\%) of small and medium enterprises of the study areas were used accrual basis of accounting -especially, business operators who engaged in merchandise and manufacturing sectors. Regarding with accounting standards, the findings indicated that, almost all (95\%) of small and medium enterprises in the study areas were followed GAAP. In fact, GAAP as standard of reporting was already shifted to the newly adopted international standards which referred to as IFRS. The survey results investigated that, the majority (88\%) of small and medium enterprises did not engaged in preparation of cash flow budget; as a result, the financial decisions of the owners' becoming poor. Again, the study revealed that, many $(83 \%)$ of small and medium enterprises of the study areas did not engaged in analyzing trends in their sales. Similarly, most (72\%) of the small and medium enterprises in the study areas were not maintained separate records for the entity and owners'.

\section{Conclusions and Recommendations 6.1 Conclusions}

Most small and medium enterprises operators have no ample education as a result, they unable to maintain core business records. The study found that, most small and medium enterprises of the study areas sometimes involved in preparation of profit and loss accounts mainly, due to lack of core accounting and businesses knowledge. The study further investigated that, majority of small and medium enterprises of the study areas adopted and using manual accounting system - especially because of the fact that, most small and medium enterprises have no basic computer skills. Concerning with accounting standards in use, for those who engaged in accounting practices, the results found that, nearly all of small and medium enterprises' small and medium enterprises who tried to maintain records were followed GAAP. Hence, the newly adopted accounting standard that is, IFRS was generally not in use in the study areas. The study concluded that, most small and medium enterprises did not involve in the preparation of cash flow budget -mainly because of knowledge about financial analysis. Similarly, the study concluded that, most small and medium enterprises in the study areas were not engaged in analyzing trends in sales. Finally, Business Entity concept suggested that, business activities should be separate \& distinct from owners' who supplied the resources and from other entities. However, the study found that, the business entity concept did not effective in small and medium enterprises of the study areas.

\subsection{Recommendations}

To boost the users of the accounting information small and medium enterprises better to improve the quality of their reports by adopting computerized accounting and internationally accepted accounting standards such as IFRS. In addition, to manage the irregularities in the accounting practices in small and medium enterprises, the government should develop sound policy and regulation. Moreover, accounting training programs for small and medium enterprises should be initiated by concerned bodies - especially, the Trade and Industry Bureaus, academic staffs, and the technical and vocational schools for those who did not know about the significance of maintaining accounting records. Most importantly, the government should put in place a regulatory body to make sure that small and medium enterprises keep proper books and prepare final accounts. Lastly, small and medium enterprise operators should give more attention to proper financial record keeping and financial reporting.

\section{References}

Ademola, M. (2012). The Roles of Record Keeping in the Survival land Growth of SMEs. Management and Business Research, pp. 12-13.

Amaoke, G.K. (2013). Accounting practices of SMEs. International Journal of Business and Management, 8(24), pp., $73-83$

Dawuda A., \& Azeko, I. (2015). An Assessment of Financial Records Keeping Behavior of Small Scale Businesses: International Journal of Finance and Accounting 4(3): 187-194.

Everaert P., Sarens, G., \& Rommel, J. (2006). Outsourcing of Accounting Tasks in SMEs: Information management Journal Vol. 35, No 1, pp 44-50.

Gitman L. 2010. Principles of managerial finance. Twelfth edition, New York: Pearson. http://www.yourarticlelibrary.com [Accessed, March, 2019].

Isaac B., Kudaze S., \& Sulemana I. (2014). Adoption of Accounting Practices and Its Effects on SMEs: Research Journal of Finance and Accounting, Vol.5, No.17.

Jones P., Simmons, G., Packham, G., Beynon-Davies, K. \& Pickernell, D. (2012). An exploration of the attitudes and strategic responses of sole proprietor micro-enterprises in adopting information and communication technology. International Small Business Journal.

Justice S., (2017). A study of Financial Accounting Practices of Small and Medium Scale Enterprises. 
International Journal of Academic Research in Business and Social Sciences Vol. 7, No. 7

Keasy K., \& Short, H. (1990). The accounting burdens facing small firms. Journal of Accounting Business Research, 20(80), pp., 307-313.

Lalin H., \& Sabir, R. I. (2010). Research on Usage and Usefulness Perception of Financial Accounting Practices in less Developing Countries. Proceedings of the 7th International Conference on Innovation \& Management, $1881-1885$

Maseko N., Manyani O., (2011). Accounting practices of SMEs. Journal of Account and Tax, 3(8) p. 171-181.

Meredith (1986). Financial Management of the Smaller Enterprise. Mc Graw Hill, Sydney, Australia.

McMahon R.G.P.,(1998). Financial reporting practices of Australian manufacturing SMEs. School of Commerce Research Paper Series.

Md. Asaduzzaman, (2016). Accounting and Financial Reporting Practices of SMEs. Malaysian Journal of Business and Economics Vol. 3, No. 1.

Mehari D. \& Pashak A., (2017). A Study on Accounting Practice and Financial Reporting in SMEs. Research on Humanities and Social Sciences.Vol.7, No.19, 2017.

Mitchell F., Reid, G., \& Smith, J., (2000). Information system development in the small firm: The use of management accounting. London: CIMA Publishing.

Tafa M., (2011). Accounting practices of small and medium sized enterprises and its effect on access to finance in Addis Ababa (MSc thesis), AAU, Ethiopia.

Okoli, B. E., (2011). Evaluation of the Accounting Systems Used by Small Scale Enterprises. Asian Journal of Business Management, 3(4), 235-240.

Olatunji, (2013). Impact of accounting record on the performance of Small and Medium Scale Enterprises (Vol. 21). (L. U. Technology, Ed.) Nigeria, Oyo, Nigeria.

Padachi, K., (2012). Why SMEs Ignore Formal Accounting Systems? -Entity Concept Explanation. International Conference on Applied and Management Sciences, 16-17, Bangkok.

Reed, R. (2010). Good Small Business Guide; How to Start and Grow Your Own Business; 2nd Edition, A \& C Black publishers Ltd, London.

Stefanou C, (2006). The Complexity and the Research Area of AIS. Journal of Enterprise Information Management. Vol. 19 No. 1, pp. 9-12.

Walker, W. and Petty, J., (2001). Financial management of the small firm. New York: Prentice-Hall.

Zhou, L. (2010). The Research on Issues and Countermeasures of Accounting Information of SMEs. International Journal of Business Management, 5(3), 223-225.

Zoubi, T.A \& Al-Khazali, O. (2011). Adopting US-GAAP or IASB Accounting Standards by the Arab Countries. International Business \& Economics Research Journal 3(10).

Yousef, B. (2013). The use of accounting information by Small and medium. Research journal of finance and accounting. Vol. 4, No. 6, pp. 169-175. 